\title{
Risk of Trypanosoma cruzi I (Kinetoplastida: Trypanosomatidae) transmission by Panstrongylus geniculatus (Hemiptera: Reduviidae) in Caracas (Metropolitan District) and neighboring States, Venezuela
}

\author{
Hernán J. Carrasco ${ }^{\mathrm{a}}$, Annhymariet Torrellas ${ }^{\mathrm{b}}$, Carlos García ${ }^{\mathrm{a}}$, \\ Maikell Segovia $^{\mathrm{a}}$, M.Dora Feliciangeli ${ }^{\mathrm{b}, *}$ \\ ${ }^{a}$ Instituto de Medicina Tropical, Facultad de Medicina, Universidad Central de Venezuela, Caracas, Venezuela \\ ${ }^{\mathrm{b}}$ BIOMED, Universidad de Carabobo, Apartado 4873, Núcleo Aragua, Maracay, Venezuela
}

Received 21 February 2005; received in revised form 9 May 2005; accepted 9 May 2005

\begin{abstract}
The collection of Panstrongylus geniculatus bugs by inhabitants of dwellings in Caracas city (Metropolitan District) and in the neighboring Miranda and Vargas Sates, Venezuela, allowed for the gathering of data on the potential role of this sylvatic triatomine bug as a vector of Chagas disease in this area. The natural infection by Trypanosoma cruzi was recorded by examining fresh and stained faeces of the bugs. Additionally, a random amplification of polymorphic DNA technique for parasite identification and group typing was employed. A dotELISA test was used to identify the gut content of the triatomine bugs with the aim of assessing and quantifying the vector-human contact. Sixty-seven specimens (76.1\%) were positive to T. cruzi (identified as T. cruzi I) and $60.2 \%$ (53/88) gave a positive reaction to the human antiserum. The human blood-positive samples included mixed blood meals with domestic animals (dog, pig and cow) (9.4\%) and with mouse (3.8\%). The overall Human Blood Index, measured as the percentage of bugs whose gut contents reacted with human antiserum on the total numbers of bugs that reacted with all the antisera tested, was $98.1 \%$. Almost $41 \%$ of the bugs that had fed on humans were also positive for T. cruzi. These data show that the feeding of $P$. geniculatus on humans does not seem to be accidental and that its rate of infection by $T$. cruzi is high in this area which is not regarded as endemic for Chagas disease by the National Control Programme. This situation is particularly striking because it occurs in and around Caracas, the capital city, where $20 \%$ of the whole population of Venezuela live, human migrations from endemic areas are continuous, people in the crowded shantytown as well as people living in high-quality country houses are equally at risk and the epidemiological cycle Didelphis marsupialis/Rattus rattus-P. geniculatus-human does appear to occur successfully.
\end{abstract}

(C) 2005 Australian Society for Parasitology Inc. Published by Elsevier Ltd. All rights reserved.

Keywords: Panstrongylus geniculatus; Trypanosoma cruzi I; Chagas disease; Venezuela

\section{Introduction}

Chagas disease control programs have primarily relied on the interruption of domestic transmission through the chemical intervention against triatomine vectors. Following the successful control of domestic species such as Rhodnius prolixus Stâl 1859 in parts of the Andean region (Acquatella et al., 1987; Feliciangeli et al., 2003) and Triatoma infestans (Klug, 1834) in the Southern Cone countries (Dias et al.,

\footnotetext{
* Corresponding author. Tel.: +58 243242 5822; fax: +58 243242 5333.

E-mail address: mdora@telcel.net.ve (M.D. Feliciangeli).
}

2002), the process of domestication of sylvatic Triatominae is now seen as the major concern facing the control of Chagas disease in the next decade (Schofield et al., 1999).

Panstrongylus geniculatus (Latreille, 1811), a triatomine bug in the Order Hemiptera, Family Reduviidae, Tribe Triatomini, is reported in 16 American countries (Dujardin et al., 2002). It is primarily linked with the enzootic transmission of Trypanosoma cruzi, often in association with armadillos (Dasypus novemcinctus) (Pifano, 1969; Sherlock and Serafim, 1972; Lent and Wigodzinsky, 1979). However, it has also been noted that adventitious flying adults enter domestic habitats attracted by light (Silvérie et al., 1964; Pifano, 1969; Lent and Wigodzinsky, 1979). 
In Venezuela, Pifano (1969) reported that people could catch adult bugs feeding on children. More recently, $P$. geniculatus has been reported in human dwellings in Colombia (Corredor et al., 1990; Guhl, F., 2002. Distribución de triatominos en la Amazonía Colombiana y su papel en la transmisión de $T$. cruzi. In: Proceedings ECLATAMCHA International Workshop on Chagas disease surveillance in the Amazon region), in Ecuador (Amunarriz et al., 1991), in Brazil (Valente et al., 1998; Rebelo et al., 1998), in Argentina (Damborsky et al., 2001) and in Peru (Cáceres et al., 2002).

The presence of immature stages in pigsites in Brazil (Valente et al., 1998) and in houses in Colombia (Amalfi, Antioquia) (Wolff and Castillo, 2000) and Venezuela, Miranda State (Reyes-Lugo and Rodriguez- Acosta, 2000) and Lara State (Feliciangeli et al., 2004), suggest that peridomestic and domestic colonisation may occur.

These new reports indicate an increasing risk of transmission of $T$. cruzi by $P$. geniculatus to humans. In Brazil, parasites isolated from this species in the vicinity of Belém, Pará State, were identified as principally zymodeme 3 (Z3) (Miles et al., 1981; Povoa et al., 1984), while T. cruzi Z1 was identified in the Island of Marajó (Valente et al., 1998) and in Lara State, Venezuela (Feliciangeli et al., 2004).

The identification of the blood meal sources of haematophagous insects is a key issue in establishing vector-host contact and in the understanding of disease transmission dynamics. Although T. cruzi is not transmitted by bite, the defecation of the infected insect faeces and urine close to the bite wound, favours the entry of the parasites, when bite is scratched or rubbed. Limited information is available in the literature on the natural feeding habits of sylvatic triatomine bugs. In this paper, we investigated the $P$. geniculatus-human contact and demonstrate that the feeding of this sylvatic species, frequently infected with T. cruzi, on humans, does not appear to be either rare or occasional.

\section{Materials and methods}

\subsection{Samples}

The blood sources for this study were taken from a sample of 88 P. geniculatus brought from inhabitants living in an area in north-central Venezuela $\left(9^{\circ} 57-10^{\circ} 38 \mathrm{~N}\right.$; $65^{\circ} 30^{\prime}-67^{\circ} 22^{\prime} \mathrm{W}$ ), which comprises the Metropolitan District and the States Miranda and Vargas (Fig. 1). The majority of specimens were collected by people of the Metropolitan District which includes the capital, Caracas $\left(10^{\circ} 23^{\prime} 18^{\prime \prime}-10^{\circ} 34^{\prime} 00^{\prime \prime} \mathrm{N} ; 66^{\circ} 51^{\prime} 30^{\prime \prime}-67^{\circ} 10^{\prime} 35^{\prime \prime} \mathrm{W}\right)$, and some municipalities of Miranda State. The ecological life zone in the Metropolitan District is moist pre-montane forest (Ewel and Madriz, 1968), with an altitude of $800 \mathrm{~m}$ above sea level, average temperature of $18-22{ }^{\circ} \mathrm{C}$ and

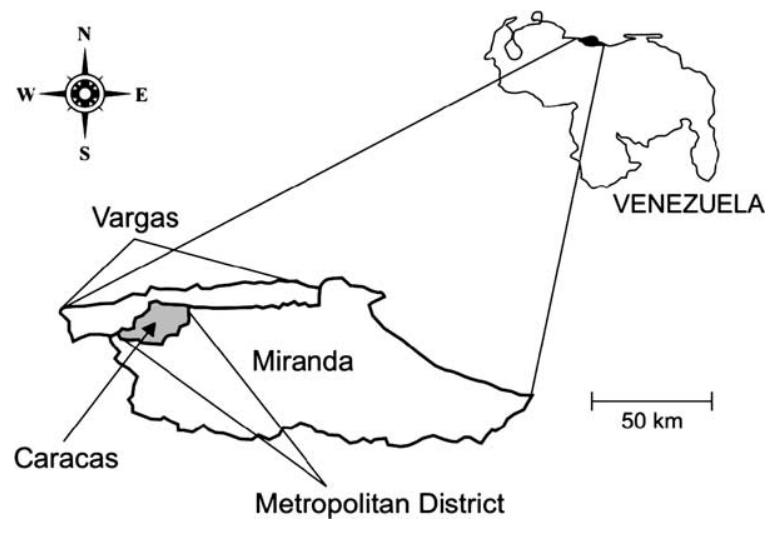

Fig. 1. Map of Venezuela showing the relative location of the area from which Panstrongylus geniculatus were collected indoors by inhabitants.

annual precipitation of $870 \mathrm{~mm}$. The population is about $4,000,000$ inhabitants, almost $20 \%$ of the whole Venezuelan population, whose migratory flows from rural areas everywhere in the country, including those endemic areas for Chagas disease, to the capital, are encouraged by the high demand for unskilled labor at comparatively high wages.

The triatomines, which also included one Eratyrus mucronatus Stal 1859 and one Panstrongylus rufotuberculatus (Champion 1899), were voluntarily brought to the Instituto de Medicina Tropical, Universidad Central de Venezuela, Caracas, by people who were referred in by personnel at the Primary Health Care Centers. They were found in houses from high quality, good quality and poor quality (shantytown), as well as in apartments of high, middle and low social classes. Some houses were located close to downtown and were not close to forest or green areas. In Caracas and the other places where the insects were found, there were many green areas with woods. Most of the neighborhoods were located beside, close to or surrounded by woodlands.

Some people complained of biting. In addition to the adults, one inhabitant brought a batch of eggs and nymphs indicating existence of a domestic colony. Each bug was kept separately in a plastic vial, coded and frozen at $-80{ }^{\circ} \mathrm{C}$ after examination of $T$. cruzi infection and isolation of parasites.

\subsection{Search and identification of T. cruzi}

When it was possible, the faeces of the bugs were examined for the presence of $T$. cruzi. All bugs were dissected and the digestive content examined using routine parasitological methods: fresh smears and Giemsa staining. Faeces from infected bugs were diluted in PBS (pH 7.4) and inoculated i.p. into laboratory mice. After 1 week, the mice were examined for the presence of blood stream parasites and subsequently every 2 days until the parasites were observed. Parasites from infected mice were grown in blood agar medium and then transferred to RPMI medium (Miles, 
1993), for further growth and DNA extraction. Genomic DNA was extracted from epimastigote forms as previously reported by Feliciangeli et al. (2004). The random amplified polymorphic DNA (RAPD) technique was used for parasite identification (T. cruzi or Trypanosoma rangeli) and group typing by comparing the pattern of bands of each isolates with reference strains representative of the main groups of T. cruzi as described by Carrasco et al. (1996) and Feliciangeli et al. (2004).

\subsection{Blood meal identification}

The method of Gomez et al. (1998) was used. Briefly, a sample of the contents of the digestive tract of each bug was absorbed on a piece of filter paper (Whatman No. 1) and kept in Eppendorf vials with silica-gel. These were eluted individually in $100 \mu \mathrm{l}$ of PBS (pH 7.4) and kept overnight at $4{ }^{\circ} \mathrm{C}$. After $24 \mathrm{~h}, 5 \mu \mathrm{l}$ of each eluate was transferred to small pieces of nitrocellulose membrane in wells of flexible polyvynil chloride multiwell plates and incubated for $1 \mathrm{~h}$ at $37^{\circ} \mathrm{C}$. The plates were blocked with $150 \mu \mathrm{l}$ of $\mathrm{PBS} / 1 \%$ bovine serum albumin (PBS-BSA) for $30 \mathrm{~min}$ at room temperature and then washed $(3 \times)$ with PBS/0.05\% Tween 20 (PBS-Tw20). IgG peroxidase antiserum conjugates against human, dog, cow, chicken, horse, pig and mouse (Sigma, St Louis, MO) were used to investigate the blood sources. Each anti IgG host-specific peroxidase conjugate was diluted in PBS-Tw20, according to previously determined ratios, mixed with $50 \mu \mathrm{l}$ of each heterologus serum to reduce cross-reactions and to enhance specificity, incubated at $37^{\circ} \mathrm{C}$ for $1 \mathrm{~h}$ and washed $(3 \times)$ with PBS-Tw20. Finally peroxidase substrate (4-chloro-naphthol) was added and the samples were incubated for $30 \mathrm{~min}$ in the dark. The reaction was stopped by washing with distilled water. The samples were considered positive if defined blue-purple spots developed on an antigen dot.

\subsection{Statistical analysis}

The data were analysed using the package EpiInfo version 6 (CDC, Atlanta, GA, USA). The significance of differences between proportions was determined using Yates' corrected $\chi^{2}$-tests and two-tailed Fisher tests. $P$-values $<0.05$ were considered to be statistically significant. Estimates of relative risks (odds ratios; OR) of infection in bugs from the three geographical areas mentioned above, and $95 \%$ confidence intervals (95\% CI) were calculated.

\section{Results}

Of the $88 P$. geniculatus adults collected, 44 (50\%) were from the Metropolitan District, 21 (23.9\%) from Miranda State and $23(26.1 \%)$ from Vargas State. The sex was recorded for 80 specimens, of which 52 (65\%) were females and $28(35 \%)$ males. All specimens were examined for Trypanosoma infection. The fresh examination of faeces and the stained slides identified 67 specimens $(76.1 \%)$ as positive for $T$. cruzi. The RAPD profiles obtained with five different primers for all the isolates included in the present study revealed that all samples fell within the TCI (Z1) main group. As shown in Fig. 2, a representative group of T. cruzi stocks from infected bugs from different sites in Caracas, generated a pattern of bands that corresponded with the profile obtained with the TCI (Z1) reference strain WA250 cl10B and showed to be clearly different to the patterns obtained with Z2 (IIb) and Z3 (IIa) reference strains. However, minor variation in the presence and size of a few bands in a range from 1.3 to $1.6 \mathrm{~KB}$ were observed between some isolates, indicating polymorphisms as can be seen in Fig. 2: track 4 (one band of $1.4 \mathrm{~KB}$ ), track 5 (two bands of 1.6 and $1.4 \mathrm{~KB}$ ), track 6 (two bands of 1.5 and $1.3 \mathrm{~KB}$ ) and track 7 (one band of $1.3 \mathrm{~KB}$ ).

In Table 1 we show the results of the dot-ELISA for the identification of the blood meal using seven antisera: $60.2 \%$ of the bugs (53/88) gave positive reaction to the human antiserum. Only one bug gave a positive reaction to the chicken antiserum and 34 were negative to all seven antisera $(38.6 \%)$. The human blood-positive samples included mixed blood meals with domestic animals (dog, pig and cow) $(9.4 \%)$ and with mouse $(3.8 \%)$. All samples were negative to anti-horse serum. The overall Human Blood Index, measured as the proportion of bugs fed on humans (including mixed meals) to the total fed, was $98.1 \%$.

Table 2 shows the results of both $T$. cruzi infection and blood meals analysis. Bugs $(40.9 \%)$ that had fed on humans were also positive to $T$. cruzi, while almost $20 \%$ were negative for $T$. cruzi; $31.8 \%$ that did not react with the antisera used were positive to $T$. cruzi and the bug that had a chicken blood meal was also positive to $T$. cruzi .

Fig. 3 shows the relative rates of infection to $T$. cruzi and human blood meal in the samples of $P$. geniculatus

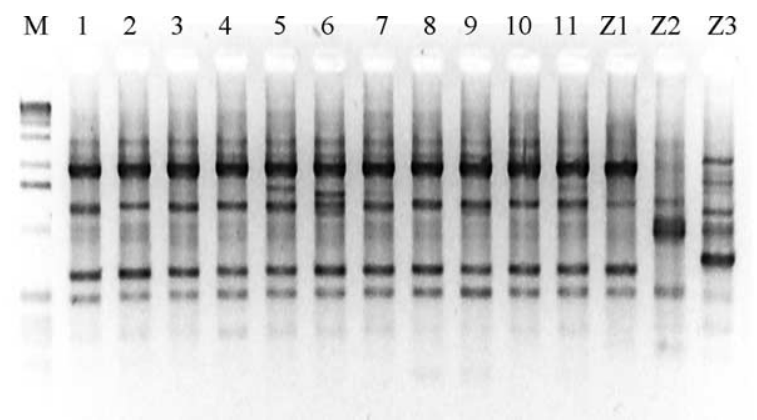

Fig. 2. Random amplified polymorphic DNA profiles of Trypanosoma cruzi stocks obtained from Panstrongylus geniculatus collected in different places in Caracas. 1, VE2603; 2, VE3703; 3, VE4803; 4, VE5103; 5, VE6603; 6, VE7303; 7, VE0704; 8, VE1004A; 9, VE1104B; 10, VE1504A; 11, VE1804. Reference strains: zymodeme 1 or TcI, Z1 =WA250c110B; zymodeme 2 or TcII, Z2 =Esmeraldo c13; zymodeme $3, \mathrm{Z3}=\mathrm{CAN}$ II. $M=1 \mathrm{~KB}$ ladder. 
Table 1

Results of the dot-ELISA for blood meal identification of Panstrongylus geniculatus collected in dwellings in north-central Venezuela

\begin{tabular}{lcc}
\hline Host & No. & $\%$ \\
\hline Human & 46 & 52.27 \\
Chicken & 1 & 1.14 \\
Human + dog & 3 & 3.41 \\
Human + mouse & 2 & 2.27 \\
Human + pig & 1 & 1.14 \\
Human + cow & 1 & 1.14 \\
Negative & 34 & 38.9 \\
Total & 88 & 100 \\
\hline
\end{tabular}

collected in the Metropolitan District, Miranda and Vargas. No significant difference in the infection rate was found in the bugs from the Metropolitan District (79.6\%) compared with Vargas State (78.3\%) (two-tailed Fisher test: $P=$ $1.000, \mathrm{df}=1)$ and from Miranda $(57.4 \%)$ (Yates' corrected $\left.\chi^{2}=2.53, P=0.116, \mathrm{df}=1\right)$. The probability for $P$. geniculatus to be infected was the same in Caracas as Vargas $(\mathrm{OR}=1.08,95 \% \mathrm{CI}=0.25-4.25)$, but almost double in Caracas when compared with Miranda State $(\mathrm{OR}=2.92$, 95\% CI $=0.82-10.58)$.

\section{Discussion}

The transmission of $T$. cruzi to humans primarily depends on three factors inherent to the bionomics of the insect vector: the presence of $T$. cruzi in the bug, the human-vector contact and the timing of diuresis/defaecation of the bug during blood meal uptake which would allow deposit of the parasite on or near the host before departing. It is thought that triatomines often deposit faeces, followed by urine, during and at the end of ingestion (Schaub and Losch, 1988). In endemic areas, these requisites are successfully fulfilled by domestic bugs. Although the intrusion of sylvatic species into human dwellings is often recorded, the evidence to assess the human-vector contact and the defecation before leaving the host is hard to collect. As a consequence, sylvatic bugs are often regarded solely as putative vectors and as a potential threat.

Panstrongylus geniculatus, despite a widespread distribution, has been traditionally regarded as a putative vector

Table 2

Trypanosoma cruzi $(T c)$ infection and blood meals in Panstrongylus geniculatus from north-central Venezuela

\begin{tabular}{lrr}
\hline & No. & $\%$ \\
\hline$T c+\mathrm{HB}$ & 36 & 40.91 \\
$T c+\mathrm{ChB}$ & 1 & 1.14 \\
$T c+\mathrm{Neg}$ & 28 & 31.82 \\
$T c-\mathrm{HB}$ & 17 & 19.32 \\
$T c-\mathrm{Neg}$ & 6 & 6.82 \\
Total & 88 & 100 \\
\hline
\end{tabular}

HB, human blood; ChB, schicken blood.

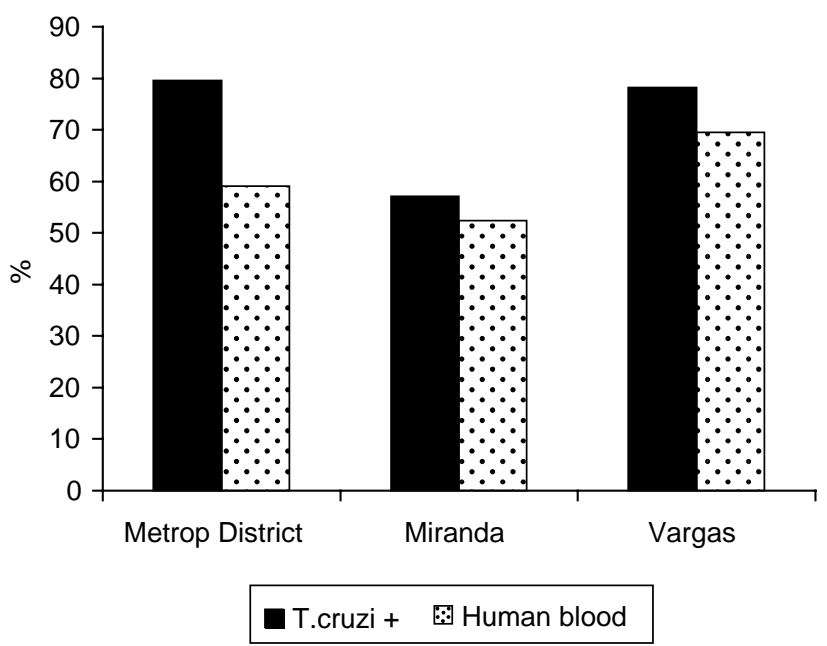

Fig. 3. Trypanosoma cruzi infection and human blood meals in Panstrongylus geniculatus collected in dwellings in north-central Venezuela.

of minor importance in the transmission of Chagas disease in Venezuela. Its natural infection by $T$. cruzi, first described by Carlos Chagas (1912) in Brazil, has been reported in the literature by several authors, e.g. $42.5 \%$ in Trinidad, West Indies (Omah-Maharaj, 1992); 16.46\% in Brazil (Valente, 1999); up to $50 \%$ in Colombia (Wolff and Castillo, 2000). In this study in north-central Venezuela, more than $70 \%$ $P$. geniculatus were found infected with T. cruzi I. The TcI (Z1) main group is widely spread in Venezuela as shown by the genetic analysis of a large number of isolates from different hosts and regions, circulating in domestic and sylvatic cycles (Carrasco, unpublished data).

To our knowledge only limited information exists on the natural feeding sources of $P$. geniculatus and this is the first robust evidence on the $P$. geniculatus - human contact. This study shows that this species not only repeatedly enters human dwellings, but it also successfully feeds on humans, as indicated by the high proportion of gut contents that reacted with human antiserum $(60.2 \%)$ and the high Human Blood Index (98.1\%) among the specimens collected by people in their houses. Therefore, the process of domestication seems feasible and it is reinforced by the presence of eggs and different instar stages of $P$. geniculatus found within a house in a very crowded neighborhood of Caracas. Negative reactions in the blood meal analysis may be due to bugs with some remnants of previous meals from other animals, probably sylvatic, that were not tested in this trial.

The timing of diuresis/defecation during or after the blood meal is recognised as the final crucial factor to guarantee transmission. Valuable information on this matter has been produced in laboratory conditions by Wolff and Castillo (2000) who offered white mice to adult $P$. geniculatus females and males. An average feeding time of 80.27 and $67.80 \mathrm{~min}$ and an average defaecation time, initiated from the start of feeding, of 55.25 and $60.42 \mathrm{~min}$ were recorded, respectively, for females and males. Faeces 
were therefore expelled during the feeding process. These results agree with the relative observations (for each species) on the negative correlation between blood meal weight and defaecation time in several triatomine species and that previous starvation positively influenced the blood intake and the defaecation time, independent of the size (Kirk and Schofield, 1987; Trumper and Gorla, 1991; Catalá, 1994; Crocco and Catalá, 1996; Bar et al., 2003). Although small species are expected to spend a shorter time for repletion and defaecation, which might increase their efficiency as vectors (e.g. $R$. prolixus), nevertheless, big sizes and longer feeding and defaecation times do not seem to hamper the transmission process. In fact, T. infestans, whose size $(21-26 \mathrm{~mm} \times 8-10 \mathrm{~mm}$ for males and $26-$ $29 \mathrm{~mm} \times 8.5-10 \mathrm{~mm}$ for females) is similar to P. geniculatus $(22-28 \mathrm{~mm} \times 7-10 \mathrm{~mm}$ for males and $22.5-29.5 \mathrm{~mm} \times$ $7-12 \mathrm{~mm}$ for females) (Lent and Wigodzinsky, 1979), is the most important vector in the South Cone.

The epidemiological implications of the defaecation timing for the transmission of $T$. cruzi was analysed in $R$. prolixus by Kirk and Schofield (1987) and in T. infestans by Trumper and Gorla (1991). They demonstrated that this is a density-dependent factor because timing depended on the amount of ingested blood, which in turn depends on the bug population density. In relation to domestic species, they concluded that the greatest risk of transmission would therefore occur in poorly colonised or newly reinfested houses where the bug density per host would be low, so the competition for feeding would also be low. From this point of view, in absence of other triatomine species, $P$. geniculatus, if present as a visitor, would have a high chance of feeding to repletion and to defecate during the feeding. Accordingly it would pose a high risk of $T$. cruzi transmission.

It is worth noting that Wolff and Castillo (2000) found that the invasion of human dwellings by $P$. geniculatus in the municipality Amalfi, Colombia, not only occurred in lighted houses, but also $24 \%$ of cases were in houses without electricity. In this case, starvation, instead of light attraction, might be one of the factors that orientates this species toward human settlements. In our samples, we found more females than males, that may indicate that starvation will induce females to disperse more frequently than males as blood meals are necessary for oogenesis. This would also indirectly favor house colonisation. However, Wolff and Castillo (2000) collected more males than females and related this ratio to a better dispersion ability of males because of their lower weight. While the explanatory factors for the orientation of $P$. geniculatus toward houses are yet to be understood, at present we suggest that $P$. geniculatus poses a great risk in Caracas city, a crowded area where Rattus rattus is abundant in the 'barrios' and Didelphis marsupialis is also widespread. Both species as potential food sources have been found highly infected with $T$. cruzi in Caracas (Urdaneta-Morales and Nironi, 1996; de Scorza et al., 1996; Herrera and Urdaneta-Morales, 1997).
Moreover, $P$. geniculatus was found in $R$. rattus burrows in Miranda State (Reyes Lugo and Rodriguez-Acosta, 2000) and D. marsupialis has been recently strongly associated with $T$. cruzi I (Yeo et al., 2004), the genotype found in $P$. geniculatus in this area.

The proportion of bugs with $T$. cruzi and human blood were similar in the samples from the Metropolitan District, Miranda and Vargas States and we might argue that the cycle D. marsupialis/R. rattus-P. geniculatus-human is not unlikely to occur in all these areas. In fact, two acute cases of fatal Chagas disease in children have been recently recorded in two hospitals in Caracas (Espinoza, pers. commun.). This is an area that is not considered to be endemic for Chagas disease and is therefore not included in the National Control Programme. Further epidemiological studies are needed in order to devise an appropriate strategy for prevention and control in this region. However, medical professionals should be aware of potential transmission to people living in this area.

\section{Acknowledgements}

This work was supported by the MCT-FONACYT, S198000388, CDCH-UCV-09-34-4097-01 and the Wellcome trust (Project no. 062984/Z/00Z).

\section{References}

Acquatella, H., Catalioti, F., Gomez-Mancebo, J.R., Dávalos, S., Villalobos, L., 1987. Long-term control of Chagas disease in Venezuela: effects on serological findings. Electrocardiographic abnormalities, and clinical outcome. Circulation 76, 556-562.

Amunarriz, M., Chico, M.E., Guderian, R.H., 1991. Chagas disease in Ecuador: a sylvatic focus in the Amazon region. J. Trop. Med. Hyg. 94, 145-149.

Bar, M.E., Milano, A.M.F., Damborsky, M.P., Oscherov, E.B., Avalos, G., 2003. Patrones de alimentación y de defecación de Triatoma rubrovaria Blanchard,1843 (Heteroptera: Reduviidae) bajo condiciones de laboratorio. http://www1.unne.edu.ar/cyt/2003/comunicaciones/06Biologicas/B-006.pdf.

Cáceres, A.G., Troyes, L., Gonzáles-Pérez, A., Llontop, E., Bonilla, C., Murias, E., Heredia, N., Velásquez, C., Yánez, C., 2002. Enfermedad de Chagas en la región nororiental del Perú. I. Triatominos (Hemiptera, Reduviidae) presentes en Cajamarca y Amazonas. Rev. Peru. Med. Exp. Salud Publ. 19, 17-23.

Carrasco, H.J., Frame, I.A., Valente, S.A., Miles, M.A., 1996. Genetic exchange as possible source of genomic diversity in sylvatic populations of Trypanosoma cruzi. Am. J. Trop. Med. Hyg. 54, 418-424.

Catalá, S.S., 1994. Bloodmeal size and nutritional status of Triatoma infestans under natural climatic conditions. Med. Vet. Entomol. 8, 104-106.

Chagas, C., 1912. Sôbre um trypanosoma do tatú. Tatusia novemcincta, transmitido pelo Triatoma geniculata Latr. (1811). Possibilidade de ser o tatú um depositário do Trypanosoma cruzi no mundo exterior. Brasil Médico 26, 305-306.

Corredor, A., Santacruz, M., Paez, S., Guatame, L.A., 1990. Distribución de los triatominos domiciliarios en Colombia. Ministerio de Salud. Instituto Nacional de Salud. Bogotá, DE. 
Crocco, L.B., Catalá, S.S., 1996. Feeding and defaecation patterns in Triatoma sordida. Mem. Inst. Oswaldo Cruz 97, 409-413.

Damborsky, M.P., Bar, M.E., Oscherov, E.B., 2001. Detección de triatominos (Hemiptera: Reduviidae) en ambientes domésticos y extradomésticos. Corrientes, Argentina. Cad. Saude Publ. 17, 843-849.

de Scorza, C., Herrera, L., Urdaneta-Morales, S., 1996. Trypanosoma (Schizotrypanum) cruzi: histopathology in mice infected with strains isolated from Didelphis marsupialis from the valley of Caracas (Venezuela). Acta Cient. Venez. 47, 244-247.

Dias, J.C., Silveira, A.C., Schofield, C.J., 2002. The impact of Chagas disease control in Latin America: a review. Mem. Inst. Oswaldo Cruz 97, 603-612.

Dujardin J.P., Schofield C.J., Panzera F., 2002. Los vectores de la Enfermedad de Chagas. Academie Royale de Sciences d'outre-mer. Memoire in $-8^{\circ}$, Nouvelle Serie, Tome 25, fasc.3, Bruxelles.

Ewel, J.J., Madriz A., 1968. Zonas de vida de Venezuela. Memoria explicativa sobre el mapa ecológico. Editorial Sucre, Caracas.

Feliciangeli, M.D., Campbell-Lendrum, D., Martinez, C., Gonzalez, D., Coleman, P., Davies, C., 2003. Chagas disease control in Venezuela: lessons for the Andean region and beyond. Trends Parasitol. 19, 44-49.

Feliciangeli, M.D., Carrasco, H., Patterson, J.S., Suarez, B., Martínez, C., Medina, M., 2004. Mixed domestic infestation by Rhodnius prolixus Stäl, 1859 and Panstrongylus geniculatus Latreille, 1811, vector incrimination, and seroprevalence for Trypanosoma cruzi among inhabitants in El Guamito, Lara State, Venezuela. Am J. Trop. Med. Hyg. 71, 501-505.

Gomez, B., Sanchez, E., Feliciangeli, M.D., 1998. Man-vector contact of phlebotomine sandflies (Diptera: Psychodidae) in nort-central Venezuela, as assessed by bloodmeal identification using Dot-ELISA. J. Am. Mosq. Control Assoc. 14, 28-32.

Herrera, L., Urdaneta-Morales, S., 1997. Synanthropic rodent reservoirs of Trypanosoma (Schizotrypanum) cruzi in the valley of Caracas, Venezuela. Rev. Inst. Med. Trop. Sao Paulo 39, 279-282.

Kirk, M.L., Schofield, C.J., 1987. Density-dependent timing of defaecation by Rhodnius prolixus, and its implications for the transmission of Trypanosoma cruzi. Trans. R. Soc. Trop. Med. Hyg. 8, 348-349.

Lent, H., Wigodzinsky, P., 1979. Revision of the Triatominae (Hemiptera: Reduviidae), and their significance as vectors of Chagas' disease. Bull. Am. Museum Nat. Hist. 163, 1-515.

Miles, M.A., 1993. Culturing and biological cloning of Trypanosoma cruzi. Methods Mol. Biol. 21, 15-28.

Miles, M.A., Povoa, M.M., Prata, A., Cedillos, R.A., De Souza, A.A., Macedo, V., 1981. Do radically dissimilar Trypanosoma cruzi strains (zymodemes) cause Venezuelan and Brazilian forms of Chagas' disease? Lancet, 1338-1340.

Omah-Maharaj, I., 1992. Studies on vectors of Trypanosoma cruzi in Trinidad, West Indies. Med. Vet. Entomol. 6, 115-120.
Pifano, F., 1969. Algunos aspectos en la ecología y epidemiología de las enfermedades endémicas con focos naturales en el área tropical, especialmente en Venezuela. Ministerio de Sanidad \& Asistencia Social Ed. Caracas.

Povoa, M.M., de Souza, A.A., Naif, R.D., Arias, J.R., Naif, M.F., Biancardi, C.B., Miles, M.A., 1984. Chagas disease in the Amazon Basin. IV. Host records of Trypanosoma cruzi zymodemes in the States of Amazonia and Rondonia, Brazil. Ann. Trop. Med. Parasitol. 78, 479-487.

Rebelo, J.M.M., Barros, V.L.L., Mendes, W.A., 1998. Triatominae species. Cad Saude Publ. 14, 187-192.

Reyes-Lugo, M., Rodriguez-Acosta, A., 2000. Domiciliation of the sylvatic Chagas disease vector Panstrongylus geniculatus Latreille, 1811 (Triatominae: Reduviidae) in Venezuela. Trans. R. Soc. Trop. Med. Hyg. 94, 508.

Schaub, G.A., Losch, P., 1988. Trypanosoma cruzi: origin of metacyclic trypomastigotes in the urine of the vector Triatoma infestans. Exp. Parasitol. 65, 174-186.

Schofield, C.J., Diotaiuti, L., Dujardin, J.P., 1999. The process of domestication in Triatominae. Mem. Inst. Oswaldo Cruz. 94 (Suppl. 1), 375-378.

Sherlock, I., Serafim, E.M., 1972. Fauna Triatominae do Estado da Bahia. I. As especies e distribução geográfica. Rev. Soc. Bras. Med. Trop. 6, 263-289.

Silvérie, R., Krämer, R., Fauran, P., Chatenay, G., 1964. Epidémiologie de la maladie de Chagas en Guyane Française: infection naturelle de Panstrongylus geniculatus. Bull Soc. Path. Exot. 57, 357-377.

Trumper, E.V., Gorla, D., 1991. Density-dependent timing of defaecation by Triatoma infestans. Trans. R. Soc. Trop. Med. Hyg. 85, 800-802.

Urdaneta-Morales, S., Nironi, I., 1996. Trypanosoma cruzi in the anal glands of urban opossums. I-Isolation and experimental infections. Mem. Inst. Oswaldo Cruz 91, 399-403.

Valente, V.C., 1999. Potential for domestication of Panstrongylus geniculatus (Latreille, 1811) (Hemiptera, Reduviidae, Triatominae) in the Municipality of Muaná, Marajó Island, State of Pará, Brazil. Mem. Inst. Oswaldo Cruz 94 (Suppl. 1), 399-400.

Valente, V.C., Valente, S.A.S., Noireau, F., Carrasco, H.J., Miles, M.A., 1998. Chagas disease in the Amazon Basin: seasonal domiciliation of Panstrongylus geniculatus with domestic pigs (Sus scrofa). J. Med. Entomol. 35, 99-103.

Wolff, M., Castillo, D., 2000. Evidencias de domesticación y aspectos biológicos de Panstrongylus geniculatus (Latreille, 1811) (Hemiptera: Reduviidae). Acta Entomol. Chil. 24, 77-83.

Yeo, M., Acosta, N., Llewellyn, M., Sánchez, H., Adamson, S., Miles, G.A., Lopez, E., Gonzalez, N., Patterson, J.S., Gaunt, M.W., Arias, A.R., Miles, M.A., 2004. Origins of Chagas disease: Didelphis species are natural hosts of Trypanosoma cruzi I and armadillos hosts of Trypanosoma cruzi II, including hybrids. Int. J. Parasitol. 35, 225-233. 